\title{
The Relationship between Self Efficacies to Academic Cheating in Madrasah Aliyah Islamiyah Sunggal
}

\author{
Mustika $^{1}$, Babby Hasmayni², Zulqarnain Nur Sani ${ }^{3}$ \\ ${ }^{1,2,3}$ Universitas Medan Area, Indonesia \\ mustika@staff.uma.ac.id,babby@staff.uma.ac.id,zulqarnainnursani@gmail.com
}

\begin{abstract}
This study aims to find out The Relationship between Self Efficacies to Academic Cheating in Madrasah Aliyah Islamiyah Sunggal. Based on the results of the calculation of Product Moment Correlation, it is known that there is a negative relationship between self-efficacy and academic cheating, where Rxy $=-0.624$ with a significant $p=0.000<0.05$. This means that the lower the selfefficacy, the higher the academic cheating. Conversely, the higher the self-efficacy, the higher the academic cheating. The effective contribution of the self efficacy variable to academic cheating in Madrasah Aliyah Islamiyah Sunggal is 38.9\%. While the remaining $61.1 \%$ is due to other factors such as moral and religious developments. In general, the results of the research on students of Madrasah Aliyah Islamiyah Sunggal had moderate self-efficacy, because the empirical average value was 89,372 which was smaller than the hypothetical average score of 93.00, while academic fraud was moderate, because the empirical average value was 204,117 which was higher greater than its hypothetical mean of 188.
\end{abstract}

Keywords

relationship, selft efficancies, academic cheating

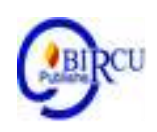

\section{Introduction}

Education is a conscious effort made by adults for human maturity which is carried out in the process of teaching and learning activities, both formally and informally. Education is expected to be able to answer all the challenges of the times and be able to foster national generations, so that people become reliable and of high quality, with strong characteristics, clear identities and able to deal with current and future problems. (Sulaiman et al, 2019)

Academic cheating that has become a habit will have negative consequences for students themselves and on a broader scale. Students who are accustomed to academic cheating will be happy to depend on the achievement of their learning outcomes on other people or certain means and not on their own abilities. Students commit academic cheating on the grounds, lazy to study, afraid of failing, and are demanded by their parents to get good grades. The urge to commit academic cheating students feels a high level of competition and feel insecure about their ability to be motivated to commit academic cheating. Students feel unsure that they are able to work on the questions given. This feeling of self-confidence is called low self efficacy (Wulandari, 2014).

According to Rettinger and Jordan (in Purnamasari, 2013), one of the factors that influence academic fraud is self-efficacy. According to Bandura (in Purnamasari, 2013) Self efficacy is the belief that someone can control a situation and produce positive results. According to Stipek \& Maddux (in Santrock, 2004) Self efficacy is the belief that self-efficacy; Powerlessness is the belief that the self is personally incapable and unsure. Bandura also added (in Santrock, 2004) that self-efficacy is an important factor to influence student achievement. 
According to Bandura (in Ormrod, 2008) individuals with a high sense of self-efficacy exert more energy when trying a new task. They are also more persistent and do not give up easily (to "try, and try again") when facing challenges. On the other hand, students with low self-efficacy will be half-hearted and give up so quickly when facing difficulties. Stating that individuals with high self-efficacy tend to learn more and achieve more than those with low self-efficacy. It is strengthened by opinion (Wolters et al., In Cahyadi) , 2009) Student academic achievement is achieved with high self-efficacy. Individuals who have high selfefficacy have self-motivation, confidence in the individual's ability to carry out the tasks that are assigned to him. This is confirmed by Wulandari's research (2014), that the higher the selfefficacy, the higher the results of student achievement, and vice versa. The lower the selfefficacy, the lower the student's academic achievement. Bandura (in Amir, 2016) states that someone with low self-efficacy will easily give up in facing problems, tend to be stressed, depressed, and have a narrow vision of what is best to solve the problem. that. Meanwhile, high self-efficacy will help someone to create a feeling of calm in facing problems or difficult activities.

\section{Review of Literature}

\subsection{Student}

In the Big Indonesian Dictionary, the definition of a student means a child who is studying, studying and attending school, while according to Shafique (in Sari, 2009) the definition of a student is a person who comes to an institution to obtain or learn several types of education. According to Djamarah (2011) is the main subject in education at any time.

Meanwhile, according to Dradjat (in Sari, 2009) students or children are "unique" individuals who have potential and experience a development process. In the development process, the child or student needs assistance whose character and style are not determined by the teacher but by the child himself, in a life together with other individuals. According to Hamalik (2001) students are one of the components in teaching, in addition to teacher factors, objectives and teaching methods. As one component, it can be said that students are the most important component among other components.

Based on the description above, it can be concluded that a student is someone who comes to an institution to get education and they are the main subject in education and have the potential and experience a development process.

\subsection{Definition of Academic Fraud}

Academic cheating behavior is defined as all forms of dishonest behavior in the academic environment committed by students towards teachers. This is stated by Davis, et al. (2009) that fraudulent behavior is "deceiving or depriving by trickery, defrauding misleading or fool nother". So according to him, academic fraud refers to actions taken by students such as lying, misleading or tricking others so that the teacher thinks that the resulting task is the result of the student's own work. Academic cheating prevents teachers from evaluating the knowledge and abilities students have on the extent of progress in their classes. The academic cheating system deceives people into believing that an academic diploma or degree signifies the level of achievement a student has.

Based on the description above, it can be concluded that academic cheating refers to actions taken by students such as lying, misleading or tricking the teacher into thinking that the resulting task is the result of the student's own work. Academic cheating prevents teachers from evaluating the knowledge and abilities students have on the extent of progress in their classes. 


\subsection{Definition of Self Efficacy}

Bandura (1997) states that self-efficacy is an individual's belief in his ability to manage and decide the behaviors needed to successfully carry out a task. According to Bandura (in Amir, 2016) Self efficacy is in practice synonymous with "self-confidence", even though "selfconfidence "Is a non-descriptive term. The term self-confidence refers to the strength of belief, for example a person can be very confident, but ultimately fail. Feist (in Amir, 2016) defines self-efficacy as human beliefs and their ability to exercise a number of control measures against function of themselves and the events in their environment. Humans who believe they can do something have the potential to change events in their environment.

Furthermore, Bandura (1997) defines self-efficacy as a person's assessment of his ability to organize and carry out a number of behaviors in accordance with the performance he has designed. In other words, self-efficacy is an opinion or belief that a person has regarding his ability to display a form of behavior and this is related to the situation faced by that person.

Meanwhile Schunk (in Amir, 2016) said that self efficacy is a person's belief in his ability to control events in his life. A person's belief is a set of determining factors and how a person behaves, how he thinks and how he reacts emotionally in overcoming a certain problem. So self-efficacy is not just a rigid estimate of a person's future actions.

Bandura (in Warsito, 2004) argues that people are more likely to engage in certain behaviors when they believe that they will be able to carry out the behavior successfully. Namely, when they have high self-efficacy. A person's decision to determine their life activities and their choice to enter a certain social environment is partly determined by considerations of their personal efficacy. People tend to avoid tasks and situations that they believe are beyond their ability and vice versa. Do so if they believe they are able to do. So, self-efficacy affects the choice of activities in a certain environment.

Self-efficacy is also defined as a person's consideration of his or her ability to achieve the desired or determined level of performance, which will influence Bandura's next actions (in Cahyadi, 2009). It should be noted that self-efficacy is one of the components of selfregulated (independence). Self-efficacy is a major determinant of individual development, their persistence in using various difficulties, and patterns of thinking and emotional reactions that they experience. Furthermore, self-efficacy beliefs play an important role in achievement motivation, relate to self-regulating the learning process, and mediate academic achievement. The concept above also relates to a person's ability to deal with pressure. If a person is faced with a situation that is potentially stressful, their self-efficacy will affect their reaction to the situation. A person will choose a certain pattern of adaptation in facing pressure and develop efforts to survive in the face of difficulties and pressures (Bandura, 1997).

In self-efficacy, there are aspects related to individual expectations. Bandura (1997) classifies these aspects into 3, namely:

\section{a. Level}

This aspect relates to the level of difficulty of the task. If the tasks assigned to individuals are arranged according to their level of difficulty, the differences in individual self-efficacy may be limited to simple, medium, or high tasks. The degree of difficulty of the task in which a person believes that the difficult task will be completed successfully. 


\section{b. Strength}

This aspect relates to the level of strength or stability of a person in his belief in doing tasks. Lower levels of self-efficacy are easily swayed by experiences that weaken him. Meanwhile, high self-efficacy will increase the business even though it is found that experiences weaken it. Individuals, who have low self-efficacy, easily give up when experiencing unpleasant experiences, while individuals with high self-efficacy of their abilities will diligently try to face difficulties and obstacles. Individuals who have high self-efficacy perceive a difficult task as a challenge that must be faced rather than as a threat or something that must be avoided.

\section{c. Generality}

This aspect relates to the broad field of work or behavior. Individuals are able to master various fields and not only focus on one task alone. Experience gradually gives rise to mastery over expectations in a specific task or behavior area, while other experiences generate conviction that encompasses a variety of tasks. From the description of the aspects of selfefficacy, it can be concluded that there are 3 aspects of self-efficacy, a. Level (Level), b. Strength (Strength), c. Generality. Bandura (1997) explains that a person's self-efficacy will affect the actions, efforts, persistence, flexibility in differences, and the realization of goals, of these goals, so that self-efficacy related to one's ability often determines the outcome before the action occurs.

\subsection{The relationship between self-efficacy and academic cheating in students}

Academic fraud committed by students is a very concerning condition in the educational environment of the nation. Many factors lead to academic cheating. One of them is low selfefficacy (Purwanto, 2007). Furthermore, Purwanto (2007) states that self-efficacy is a mental punda for students in academic achievement, in this case to achieve good results students do not get it by doing everything they can.

All means of academic cheating are not only mental damage to students but also can damage the coordinates of the education system in Indonesia. Therefore, the factors that can cause academic fraud should be addressed as soon as possible if it has occurred or is prevented from occurring (Hartinah, 2008).

Student academic fraud can be controlled by having good self-efficacy in a student. The formation of good self-efficacy is not only spontaneous in students, but can be done through parenting styles. With good self-efficacy, academic fraud by a student will not occur (Hartinah, 2008)

In line with the above opinion, Uno (2005) also said that a student must have self-belief in learning. Self-confidence in doing things independently and in the right way, not breaking new rules or often called cheating. According to Grasser (in Uno, 2005) Good self-confidence will form effective and efficient learning in students. Students know by themselves what learning methods must be done to be able to complete assignments or during school exams. And in this condition, there will be no academic cheating by students.

According to Bouffart et al (in Warsito, 2004) that students with high self-efficacy who are successful in solving problems appear to have greater performance and last longer than students with lower self-efficacy do. Students who are willing to strive to achieve high academic achievements will try to find effective and efficient ways to fulfill them. 


\section{Research Method}

This research uses a correlational quantitative approach because in its implementation it looks for as much data as possible and then tries to describe it as clearly as possible. Quantitative research is a research method based on postitivism philosophy, used to research on a particular population or sample. Data collection uses research instruments, data analysis quantitative / statistical in nature with the aim of testing the hypothesis that is being established (Sugiono, 2012).

The term variable can be defined as anything that will be the object of research observation. It is often stated that research variables are factors that play a role in the events or symptoms to be studied (Suryabrata, 2011).

The variables in this study include:

Independent variable: Self Efficacy (X)

The dependent variable: Academic Fraud (Y)

In this study, the researcher conducted hypothesis testing to explain the relationship between the independent and dependent variables. Therefore, the appropriate design for this study is to use a quantitative approach because the data obtained is related to numbers that allow statistical analysis techniques to be used to determine the relationship between student self-efficacy and academic fraud in students of Madrasah Aliyah Islamiyyah Sunggal.

Self-efficacy is an individual's belief that he is able to do something in a certain situation successfully. This self-efficacy data was obtained from the self-efficacy scale compiled by the researcher based on the self-efficacy aspects of Bandura (1997), namely, 1. level, 2. Strength, and 3.Generality.

Academic fraud is defined as behavior that is carried out by students on purpose, including several forms of behavior such as violations of rules in completing assignments and exams. Academic fraud data is obtained from a scale compiled by researchers in the forms of academic cheating from Whitley (in Davis, 2009), namely: 1. Use of notes during exams, 2. Copying other people's answers during the exam, 3. Using dishonest methods to find out what to test, 4. Copying exam answers from other people without the person's knowledge, 5. Helping others to cheat, 6 . Cheating in various ways, 7. Copying assignments of scientific papers other people and admit it as their own work, 8. Falsifying bibliography, 9. Cooperating with teachers to complete individual assignments, 10. Copying several sentences (including from the internet) without entering, 11. information into bibliography, 10. Buying scientific papers from others, 12. Using false excuses to prolong assignment submissions.

The population is the origin of the samples taken. According to (Sudjana, 1996) population is the totality of all possible values, both the results of calculating and the results of measuring both qualitative and quantitative characteristics of a complete and clear set of objects. According to (Hadjar, 1996) the population is a large group of individuals who have the same general characteristics. (Nazir, 1988) sees population as a collection of individuals with predetermined qualities and characteristics. Quality and characteristics are determined by the variables. (Arikunto, 1989) calls research involving all individuals in a group to be the subject as a population study. The population in this study were 146 students of Madrasah Aliyah Islamiyah Sunggal. 
Table. 1 Research Sample

\begin{tabular}{|l|c|c|c|}
\hline \multicolumn{1}{|c|}{ Class } & Male & Female & Total \\
\hline $\mathrm{X}(10)-\mathrm{A}$ & 18 & 12 & 30 \\
\hline $\mathrm{X}(10)-\mathrm{B}$ & 19 & 10 & 29 \\
\hline $\mathrm{XI}(11)-\mathrm{A}$ & 5 & 13 & 18 \\
\hline $\mathrm{XI}(11)-\mathrm{B}$ & 8 & 17 & 25 \\
\hline TOTAL $=$ & \multicolumn{3}{|l}{} \\
\hline
\end{tabular}

Before being used in the study, a second try out of the questionnaire was carried out (selfefficacy and student academic fraud). To test the validity of the measuring instrument used Product Moment analysis technique (Pearson).

$$
r x y=\frac{\sum x y \frac{(\Sigma x)(\Sigma y)}{N}}{\sqrt{\left(\sum x^{2}-\frac{\left(\sum x\right)^{2}}{N}\right)\left(\sum y^{2}-\frac{\left(\sum y\right)^{2}}{N}\right)}}
$$

Information:

$\mathrm{r} \quad$ : The correlation coefficient between variable $\mathrm{X}$ (subject score per item) and variable Y (total subject score of all items).

$\Sigma x y \quad$ : The sum of the multiplication results between variable $X$ and variable $Y$.

$\Sigma X \quad$ : The sum of the overall scores of the subjects for each item

$\Sigma Y \quad$ : The sum of the item's overall score on the subject

$\Sigma X^{2} \quad$ : The sum of the squares of the $X$ score

$\Sigma Y^{2}:$ The sum of the squares of the $Y$ score

$\mathrm{N}$ : Number of subjects

The validity value of each item (Pearson product moment coefficient r) actually still needs to be corrected due to excess weight. This overweight occurs because the item scores that are correlated with the total score are included as a component of the total score, this causes the $r$ coefficient to be larger (Hadi, 2004). The formula for cleaning this excess weight is used the part whole formula, namely:

$$
r b t=\frac{r x y(S D x)(S D y)}{\sqrt{(S D x)^{2}+(S D y)^{2}-2 r x y S D x S D y}}
$$

Information:

rbt: Correlation coefficient after corrected with whole parts.

rxy: The correlation coefficient before correction.

SDx: Standard deviation of items

SDy: Total standard deviation

The items on each item of the research instrument are then added up by the total score. For $\mathrm{N}=10$, the total significance is $5 \%$, the acceptance limit of $\mathrm{r}$ table $=0.632$. The instrument is said to be valid if the calculated $r$ value for all questions is greater than $r$ table at a significant level of 0.05 (Sugiyono, 2005). Tested with the SPSS (Statistical Package For Social Science) program for windows. 
The reliability of the measuring instrument shows the extent to which the measurement results with these tools can be trusted (Suryabrata, 2005) That is, the measurement results can be trusted if in several measurements of the same subject group, relatively the same results are obtained, if the aspects measured in the subject are not yet. changed. Relative understanding indicates that there is tolerance for small differences between measurement results (Azwar, 2007). The research instrument reliability testing was carried out with the Cronbach Alpha Coefficient and the calculation was done through SPSS. Using the following formula:

$$
{ }^{\mathrm{r}} 11=\left(\frac{n}{n-1}\right)\left(1 \frac{\sum i^{2} \sigma}{\sigma i 2}\right)
$$

Information
$\mathrm{r} 11$
$\mathrm{n}$
$\sum i^{2} \sigma$
$\sigma_{1}{ }^{2}$

: The reliability of the instrument being sought

: The number of items

: The number of variations in the score of each question item

: Total variance

The research data will be analyzed by using the produck moment technique, with the main objective of this study, namely to see if there is a relationship between Self Efficacy and Academic Fraud in Madrasah Aliyah Islamiyah Sunggal Students. All data were analyzed by a computer system through the statistical program SPSS (Statistical Package For Social Science) for windows. Before data analysis was submitted, first the research variables were carried out which included:

The purpose of this normality test is to find out whether the distribution of data from the study of each variable, namely the independent variable and the dependent variable, has spread normally. All data were analyzed using a computer system through the statistical program SPSS (Statistical Package for Social Science) for windows. Using the following formula:

$$
x^{2}=\sum_{i=}^{k} \frac{(O i-E i)^{2}}{E i}
$$

Information

$\mathrm{Oi}=$ frequency of observation results in the ith classification

$\mathrm{Ei}=$ expected frequency in the ith classification

The purpose of this linearity test is to find out whether the independent variables and the dependent variable have a linear relationship or not. All data are analyzed by a computer system through the SPSS (Statistical Package For Social Science) statistical program for windows.

The data analysis technique used in this study is the product moment correlation technique from Kolmogorov Smirnov. The reason for using this technique is because this study aims to see the relationship between one independent variable and the dependent variable.

According to Arikunto (2013), the formula for the product comment technique is as follows:

$$
r x y=\Sigma X Y-\Sigma \mathrm{X} \Sigma \mathrm{YN} \Sigma X^{2}-\Sigma X^{2} \mathrm{~N} \Sigma Y^{2}-\Sigma \mathrm{YN}
$$

Information:

$r x y=$ The correlation coefficient between the independent variable $\mathrm{X}$ and the dependent variable Y

$\Sigma X Y \quad=$ The sum of the product of the variables $\mathrm{X}$ and $\mathrm{Y}$ 
$\Sigma \mathrm{X}=$ The total score of the independent variable $\mathrm{X}$

$\Sigma Y \quad=$ The number of scores for the dependent variable $\mathrm{Y}$

$\Sigma X^{2}=$ The sum of the squares of the $\mathrm{X}$ score

$\Sigma Y^{2}=$ The sum of the squares of the Y score

$\mathrm{N} \quad=$ Number of subjects

All data were analyzed using a computer system through the statistical program SPSS (Statistical Package for Social Science) for windows. Using the following formula:

$$
r_{x y}=\frac{\sum x y}{\sqrt{\Sigma x^{2} y^{2}}}
$$

Where in:

$$
\begin{array}{ll}
\mathrm{r}_{\mathrm{xy}} & =\text { koefisien antara variabel } \mathrm{x} \text { dengan } \mathrm{y} \\
\mathrm{x} & =\left(\mathrm{x}_{\mathrm{i}}-\mathrm{x}\right) \\
\mathrm{y} & =\left(\mathrm{y}_{\mathrm{i}}-\mathrm{y}\right)
\end{array}
$$

\section{Result and Discussion}

This section describes the implementation of research, in the form of research orientation and all preparations that have been made, research implementation, research results and discussion.

Table 2. Item Distribution of Self Efficacy Scale Before Trial

\begin{tabular}{|c|c|c|c|}
\hline \multirow{2}{*}{ NO } & \multirow{2}{*}{$\begin{array}{c}\text { SELF EFFICACY } \\
\text { ASPECT }\end{array}$} & Favourable & Unfavourable \\
\cline { 3 - 4 } & Level & $2,5,17,23,27,29$ & $1,6,20,22,25,32$ \\
\hline 1 & Power & $3,4,10,12,13,16$ & $7,18,21,24,26,35$ \\
\hline 2 & Generalities & $9,14,15,19,28,31$ & $8,11,30,33,34,36$ \\
\hline 3 & TOTAL & $\mathbf{3 6}$ QUESTION \\
\hline \multicolumn{3}{|c|}{}
\end{tabular}

For favorite items, SS choice will get a score of 5, choice $S$ will get a score of 4 , choice $\mathrm{N}$ will get a score of 3 , TS choice will get a score of 2, and the STS choice will get a score of

\begin{tabular}{|c|c|c|c|c|}
\hline NO. & FORM & ITEM & \multicolumn{2}{|c|}{ POLARIZATION } \\
\hline \multirow[t]{3}{*}{1.} & \multirow{3}{*}{ Using notes during exams } & 1. & Yes & No \\
\hline & & 2. & Always & Never \\
\hline & & 3. & Be brave & Afraid \\
\hline \multirow[t]{4}{*}{2.} & \multirow[t]{4}{*}{ Copy other people's answers } & 4. & Yes & No \\
\hline & & 5. & Always & Never \\
\hline & & 6. & Be brave & Afraid \\
\hline & & 7. & All & Little \\
\hline
\end{tabular}
1. Whereas for unfavorable items selected SS will get score 1, choice S gets a score of 2, choice $\mathrm{N}$ will get a score of 3 , choice TS will get a score of 4, and choice STS will get a score of 5.

Table 3. Distribution of Points on Academic Fraud Behavior Scale before Trial 


\begin{tabular}{|c|c|c|c|c|}
\hline \multirow[t]{3}{*}{3.} & \multirow{3}{*}{$\begin{array}{l}\text { Using cellphones during study and } \\
\text { exams }\end{array}$} & 8. & Yes & No \\
\hline & & 9. & Always & Never \\
\hline & & 10. & Be brave & Afraid \\
\hline \multirow[t]{3}{*}{4.} & \multirow[t]{3}{*}{ Help others to cheat } & 11. & Happy & Hate \\
\hline & & 12. & Always & Never \\
\hline & & 13. & Like it & Do not like \\
\hline \multirow[t]{3}{*}{5.} & \multirow{3}{*}{$\begin{array}{l}\text { Copying other people's work and } \\
\text { acknowledging it as one's own work }\end{array}$} & 14. & Always & Never \\
\hline & & 15. & Confidence & Shy \\
\hline & & 16. & Be brave & Afraid \\
\hline \multirow[t]{3}{*}{6.} & \multirow[t]{3}{*}{ Faking bibliography in making papers } & 17. & Always & Never \\
\hline & & 18. & All & a little \\
\hline & & 19. & Be brave & Afraid \\
\hline \multirow[t]{3}{*}{7.} & \multirow{3}{*}{$\begin{array}{l}\text { Cooperate and copy the work of friends } \\
\text { to do individual assignments }\end{array}$} & 20. & Happy & Hate \\
\hline & & 21. & Quiet & Anxious \\
\hline & & 22. & Comfortable & Risih \\
\hline \multirow[t]{3}{*}{8.} & \multirow{3}{*}{$\begin{array}{l}\text { Use a variety of reasons to extend } \\
\text { assignment submissions }\end{array}$} & 23. & Always & Never \\
\hline & & 24. & Like it & Hate \\
\hline & & 25. & Confidence & Shy \\
\hline \multirow[t]{5}{*}{9.} & \multirow{5}{*}{$\begin{array}{l}\text { Cheating while taking } \\
\text { exams }\end{array}$} & 26. & Always & Never \\
\hline & & 27. & Like it & Hate \\
\hline & & 28. & & Shy \\
\hline & & 29. & Be brave & Afraid \\
\hline & & 30. & Relax & Panic \\
\hline \multirow[t]{5}{*}{10.} & \multirow[t]{5}{*}{ Team up with friends during exams } & 31. & Useful & Useless \\
\hline & & 32. & Quiet & Anxious \\
\hline & & 33. & Comfortable & Risih \\
\hline & & 34. & Be brave & Afraid \\
\hline & & 35. & Relax & Panic \\
\hline \multirow[t]{3}{*}{11.} & \multirow{3}{*}{$\begin{array}{l}\text { Purchasing / requesting answer keys for } \\
\text { exams by parties outside the school }\end{array}$} & 36. & Be brave & Afraid \\
\hline & & 37. & Useful & Useless \\
\hline & & 38. & Relax & Panic \\
\hline \multirow[t]{5}{*}{12.} & \multirow{5}{*}{$\begin{array}{l}\text { Stealing / asking questions and answers } \\
\text { to exams in other classes }\end{array}$} & 39. & Be brave & Afraid \\
\hline & & 40. & Useful & Useless \\
\hline & & 41. & Relax & Panic \\
\hline & & 42. & Like it & Hate \\
\hline & & 43. & Always & Never \\
\hline \multirow[t]{5}{*}{13.} & \multirow[t]{5}{*}{ Arrive early to finish homework } & 44. & Be brave & Afraid \\
\hline & & 45. & Useful & Useless \\
\hline & & 46. & Relax & Panic \\
\hline & & 47. & Like it & Benci \\
\hline & & 48. & Always & Never \\
\hline
\end{tabular}

Based on the validity and reliability test of measuring instruments, it is known that the self-efficacy scale of 36 items, there are 5 items that fail, have a Corrected Item-Total Correlation score (rxy difference power index) <0.3; namely items number 6, 9, 18, 28, 32 . And 31 valid items have a Corrected Item-Total Correlation score (rxy difference power 
index) $>0.3$; with moving scores from $\mathrm{rbt}=0.344$ to $\mathrm{rbt}=0.728$, with a CronbachAlpha reliability score of 0.937 (the scale is classified as reliable).

Table 4. Self Efficacy Scale Item Distribution After Trial

\begin{tabular}{|c|c|c|c|c|c|c|}
\hline \multirow{3}{*}{$\mathrm{NO}$} & \multirow{3}{*}{$\begin{array}{c}\text { SELF } \\
\text { EFFICACY } \\
\text { ASPECT }\end{array}$} & \multicolumn{4}{|c|}{ ITEM NUMBER } & \multirow{3}{*}{ TOTAL } \\
\hline & & \multicolumn{2}{|c|}{ FAVOURABLE } & \multicolumn{2}{|c|}{ UNFAVOURABLE } & \\
\hline & & VALID & GUGUR & VALID & GUGUR & \\
\hline 1. & Level & $2,5,17,23,27,29$ & - & $1,20,22,25$ & 6,32 & 12 \\
\hline 2. & Power & $3,4,10,12,13,16$ & - & $7,21,24,26,35$ & 18 & 12 \\
\hline 3. & Generalities & $14,15,19,31$ & 9,28 & $8,11,30,33,34,36$ & - & 12 \\
\hline
\end{tabular}

While the scale of academic cheating of 48 items, there is 1 item that failed has a Corrected Item-Total Correlation score (rxy difference power index) $<0.3$; namely item number 45. 47 valid items, which have a Corrected Item-Total Correlation score (index difference power rxy)>0.3; with moving scores from $\mathrm{rbt}=0.375$ to $\mathrm{rbt}=0.797$, with a CronbachAlpha reliability score of 0.972 (the scale is classified as reliable).

Table 5. Distribution of Academic Fraud Scale Items after Trial

\begin{tabular}{|l|l|c|c|}
\hline \multirow{2}{*}{ NO. } & \multicolumn{1}{|c|}{ FORM } & \multicolumn{1}{|c|}{ ITEM NUMBR } \\
\cline { 3 - 4 } & & VALID & GUGUR \\
\hline 1. & Using notes during exams & $1,2,3$ & - \\
\hline 2. & Copy other people's answers & $4,5,6,7$ & - \\
\hline 3. & Using cellphones during study and exams & $8,9,10$ & - \\
\hline 4. & Help others to cheat & $11,12,13$ & - \\
\hline 5. & $\begin{array}{l}\text { Copying other people's work and acknowledging } \\
\text { it as one's own work }\end{array}$ & $14,15,16$ & - \\
\hline 6. & Faking bibliography in making papers & $17,18,19$ & - \\
\hline 7. & $\begin{array}{l}\text { Cooperate and copy the work of friends to do } \\
\text { individual assignments }\end{array}$ & $20,21,22$ & - \\
\hline 8. & $\begin{array}{l}\text { Use a variety of reasons to extend assignment } \\
\text { submissions }\end{array}$ & $23,24,25$ & - \\
\hline 9. & Cheating while taking exams & $26,27,28,29,30$ & - \\
\hline 10. & Team up with friends during exams & $31,32,33,34,35$ & - \\
\hline 11. & $\begin{array}{l}\text { Purchasing / requesting answer keys for exams } \\
\text { by parties outside the school }\end{array}$ & $36,37,38$ & - \\
\hline 12. & $\begin{array}{l}\text { Stealing / asking questions and answers to } \\
\text { exams in other classes }\end{array}$ & $39,40,41,42$, & - \\
\hline 13. & Arrive early to finish homework & $44,46,47,48$ & 45 \\
\hline
\end{tabular}

After the items were analyzed using the Product Moment Analysis correlation technique, it was then continued with the reliability analysis (reliability). The scale reliability test technique used Cronbach Alpha. The reliability index obtained by the self-efficacy scale was $\mathrm{rtt}=0.937$. While the reliability index obtained by the scale of academic fraud is $\mathrm{rtt}=0.972$. This shows that the scale compiled in this study is declared reliable, which can be used when revealing academic self-efficacy and fraud. 
Table 6. Reliability of the Self Efficacy Scale

\begin{tabular}{|r|r|}
\hline $\begin{array}{c}\text { Cronbach's } \\
\text { Alpha }\end{array}$ & N of Items \\
\hline .937 & \\
\hline
\end{tabular}

Table 7. Academic Fraud Scale Reliability

\begin{tabular}{|r|r|}
\hline Cronbach's Alpha & N of Items \\
\hline .972 & 48 \\
\hline
\end{tabular}

The distribution normality test was analyzed using the research data distribution normality test using the Kolmogorov-Smirnov Goodness of Fit Test technique. From the normality test results, it is known that the distribution of academic fraud variable data is normally distributed. This is indicated by the Kolmogorov-Smirnov coefficient of 0.083 with p> 0.05 .

Table 8. Summary of Distribution Normality Test Results

\begin{tabular}{|c|c|c|c|c|c|}
\hline Variabel & AVERAGE & SB/SD & K-S & P & Information \\
\hline Academic cheating & 204.117 & 30.446 & 0.083 & 0.080 & Normal \\
\hline
\end{tabular}

Information:

$\begin{array}{ll}\text { AVERAGE } & =\text { Average value } \\ \text { K-S } & =\text { Kolmogorov-Smirnov coefficient } \\ \mathrm{SB} & =\text { Standard Deviation (Standard Deviation) } \\ \mathrm{p} & =\text { Significance }\end{array}$

The linearity test of the relationship which is intended to determine the degree of the relationship between the independent variable and the dependent variable means whether selfefficacy can explain the emergence of academic fraud, namely the increase or decrease in the value of the $\mathrm{Y}$ axis (academic fraud) along with the increase or decrease in the value of the $\mathrm{X}$ axis (self efficacy)

Based on the linearity test, it can be seen whether the independent variable and the dependent variable can or cannot be analyzed correlatively. The results of the analysis show that the independent variable (self-efficacy) has a linearity relationship with the dependent variable (academic fraud).

As a criterion, if the $p$ difference is $<0.05$ then it is stated to have a linear degree of relationship. From the results of the linearity test, it is known that the variable self-efficacy and academic fraud have a linear relationship. This is indicated by the coefficient of $F=67.766$ with $\mathrm{p}<0.05$

Table 9. Summary of Relationship Linearity Test Results

\begin{tabular}{|c|c|c|c|}
\hline CORRELATIONAL & F Different & p Different & INFORMATION \\
\hline $\mathrm{X}-\mathrm{Y}$ & 67.766 & 0.000 & Linier \\
\hline
\end{tabular}

Information:

$\mathrm{X}=$ Self efficacy

$\mathrm{Y} \quad=$ Academic cheating

F Different $=$ Linearity coefficient

$\mathrm{p}$ Different $=$ Significance 
Based on the results of the analysis with the Product Moment $r$ Correlation Analysis Method, it is known that there is a negative relationship between self-efficacy and academic fraud, where Rxy $=-0.624$ with a significant $p=0.05$. This means that the higher the selfefficacy, the lower the academic cheating.

The determinant coefficient (R2) of the relationship between the independent variable $\mathrm{X}$ and the dependent variable $\mathrm{Y}$ is equal to $\mathrm{R} 2=0.389$. This shows that self-efficacy contributes or contributes effectively to academic fraud by $38.9 \%$. The table below is a summary of the results of the $r$ Product Moment Analysis calculation.

Table 10. Summary of Calculation of Product Moment $r$ Analysis

\begin{tabular}{|c|c|c|c|c|c|}
\hline Statistic & Coefisien $\left(\mathbf{R}_{\mathbf{x y}}\right)$ & Coef. Det. $\left(\mathbf{R}^{\mathbf{2}}\right)$ & $\mathbf{P}$ & BE\% & Information \\
\hline $\mathrm{X}-\mathrm{Y}$ & -0.624 & 0.389 & 0.000 & $38.9 \%$ & Signifikan \\
\hline
\end{tabular}

Information:

$\mathrm{X} \quad=$ Self efficacy

$\mathrm{Y} \quad=$ Academic cheating

$\mathrm{r}_{\mathrm{xy}} \quad=$ The coefficient of the relationship between $\mathrm{X}$ and $\mathrm{Y}$

$\mathrm{r}^{2} \quad=$ The coefficient of determinant $\mathrm{X}$ against $\mathrm{Y}$

$\mathrm{p}=$ Chances of error

$\mathrm{BE} \%=$ Weight of the effective contribution of $\mathrm{X}$ to $\mathrm{Y}$ in percent

Ket $=$ Significance

For the self-efficacy variable, the number of valid items is 31 items formatted on a Likert scale in 5 answer choices, then the hypothetical mean is $\{(31 X 1)+(31 X 5)\}: 2=93$. Then for the academic fraud variable the number of items used is: valid is a total of 47 items formatted with a semantic differential scale in 7 answer choices, the hypothetical meaning is $\{(47 \mathrm{X} 1)+$ $(47 \times 7)\}: 2=188$.

Based on data analysis, as seen from the distribution normality test analysis, it is known that the empirical mean of the self-efficacy variable is 89.37 , while for the academic fraud variable, the empirical mean is 204.11 .

In an effort to determine the conditions of self-efficacy and academic fraud, it is necessary to compare the empirical mean / average value with the hypothetical mean / average value by taking into account the magnitude of the SD number of each variable. For the selfefficacy variable the SD number is 24,178 , while for the academic cheating variable the SD number is 30,446 .

From the magnitude of the SD number, then for the self efficacy variable, if the hypothetical mean / average value <mean / empirical average value, where the difference exceeds the SD number, it is stated that the self efficacy is high and if the mean / average value is hypothetical <mean / average empirical value, where the difference does not exceed the SD number, it is stated that the self-efficacy is low. If the hypothetical mean / average value > the empirical mean / average value, where the difference exceeds the Standard Deviation number, it is stated that self-efficacy is low. If the hypothetical mean / average value> the empirical mean / average value, where the difference does not exceed the Standard Deviation number, it is stated that the self-efficacy is classified as moderate. 


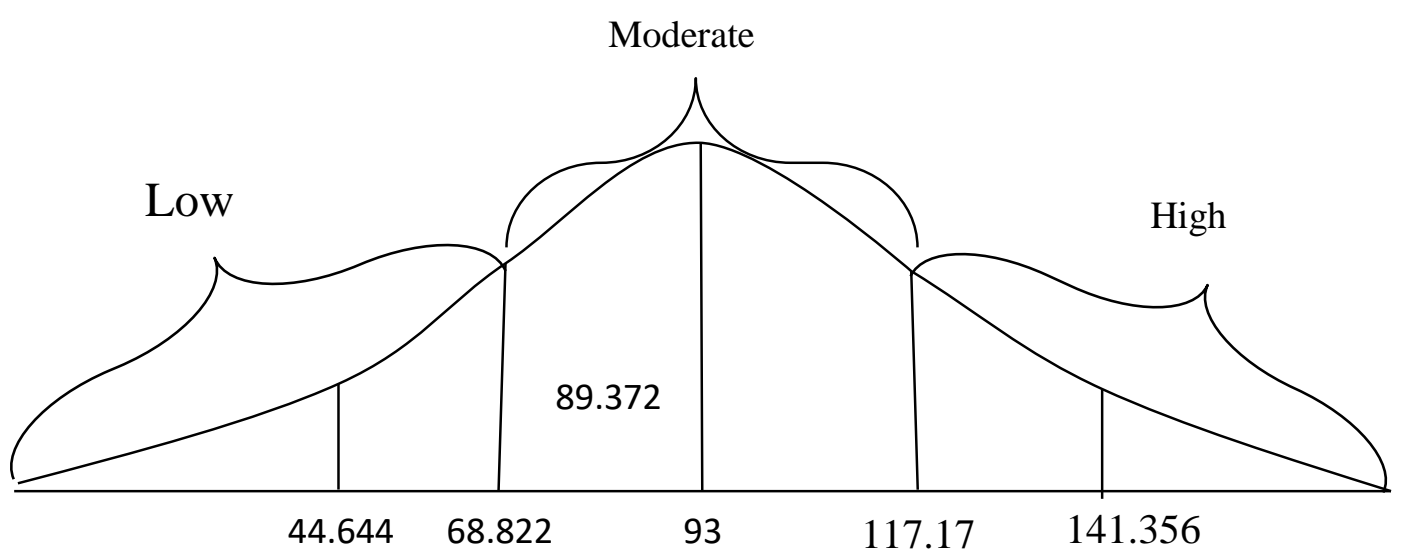

$95.19 \quad 109.38$

Figure 1. Self Efficacy Condition

For the academic fraud variable, if the hypothetical mean / average value <mean / empirical average value, where the difference exceeds the SD number, it is stated that academic fraud is high and if the hypothetical mean / average value <mean / average value- empirical average, where the difference does not exceed the SD number, it is stated that the academic cheating is moderate. If the hypothetical mean / average value> the empirical mean / average value, where the difference exceeds the Standard Deviation number, it is stated that the academic fraud is low, whereas if the hypothetical mean / average value> the empirical mean / average value, where the difference does not exceed the Standard Deviation number, it is stated that the individual has high academic fraud.

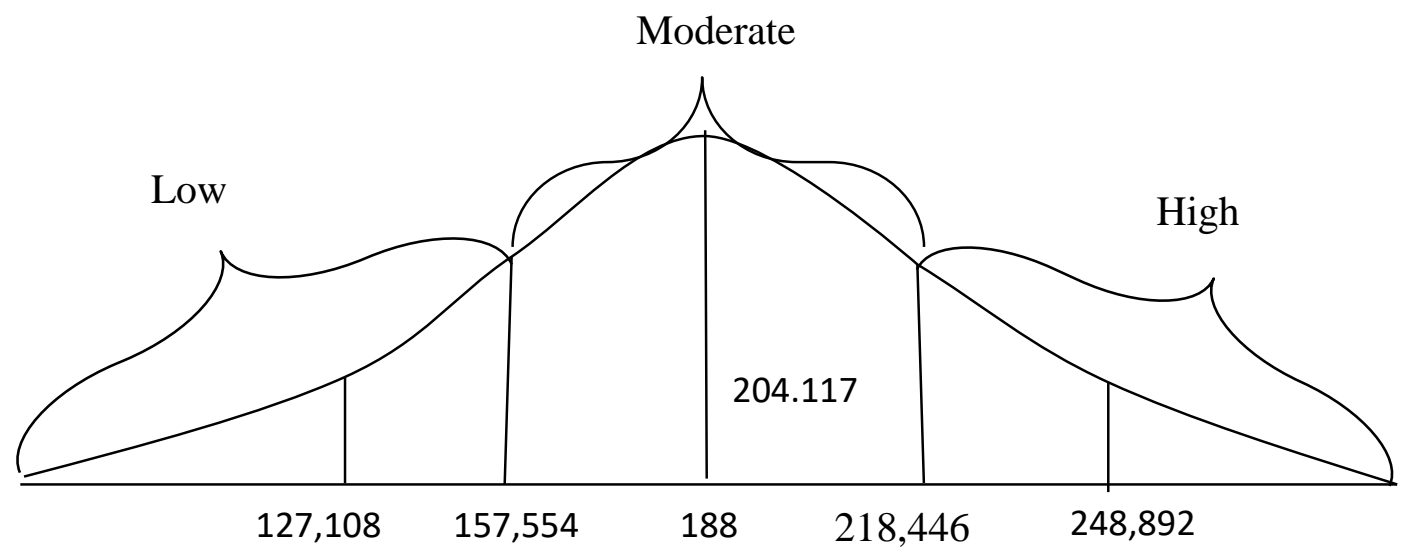

95.19109 .38

Figure 2. Academic Cheating Conditions

A complete description of the comparison of the hypothetical mean / average value with the empirical mean / average can be seen in the table below. 
Table 11. Results of the Calculation of the Hypothetical and Empirical Mean Value

\begin{tabular}{|c|c|c|c|c|}
\hline \multirow{2}{*}{ Variable } & \multirow{2}{*}{ SB / SD } & \multicolumn{2}{|c|}{ Average value } & \multirow{2}{*}{ Information } \\
\cline { 3 - 4 } & & Hypothetical & Empirical & \\
\hline Self efficacy & 24.178 & 93 & 89.372 & Moderate \\
\hline $\begin{array}{c}\text { Academic } \\
\text { cheating }\end{array}$ & 30.446 & 188 & 204.117 & Moderate \\
\hline
\end{tabular}

\section{Conclusion}

Based on the results of the calculation of Product Moment Correlation, it is known that there is a negative relationship between self-efficacy and academic cheating, where Rxy = 0.624 with a significant $p=0.000<0.05$. This means that the lower the self-efficacy, the higher the academic cheating. Conversely, the higher the self-efficacy, the higher the academic cheating. The effective contribution of the self efficacy variable to academic cheating in Madrasah Aliyah Islamiyah Sunggal is $38.9 \%$. While the remaining $61.1 \%$ is due to other factors such as moral and religious developments.

In general, the results of the research on students of Madrasah Aliyah Islamiyah Sunggal had moderate self-efficacy, because the empirical average value was 89,372 which was smaller than the hypothetical average score of 93.00, while academic fraud was moderate, because the empirical average value was 204,117 which was higher greater than its hypothetical mean of 188.

\section{References}

Amir Zubaidah, Risnawati. (2016). Psikologi Pembelajaran Matematika. Yogyakarta: Aswaja Pressindo.

Anderman, M \& Murdock, B. (2007). Psychology of academic cheating. Elsevier Academic Press: USA.

Arikunto, Suharsimi. (1998). Prosedur Penelitian, Suatu Pendekatan Praktek. Jakarta:Rineka Cipta.

Bandura, Albert. (1997). Self Efficacy In Changing Societies. Cambridge University Press.

Bintoro, Wahyu, et al. (2013). Hubungan Self Regulated Learning dengan Kecurangan Akademik Mahasiswa. Vol: 2 no: 1, Oktober 2013. (online). Diakses pada tanggal 27 November 2016.http://journal.unnes.ac.id/sju/index.php/epj/article/view/2587

Cahyadi Surya, Agustiani Hendriati. (2009). Self Efficacy dan Regulasi Belajar Sebagai Prediktor Prestasi Akademik Mahasiswa Fakultas Psikologi Universitas Padjadjaran. Jurnal Psikologi, Vol. 24, Nomor 2, hal: Bandung: Fakultas Psikologi Universitas Padjadjaran

Clariana, et al. (2013). Academic cheating and gender differences in Barcelona (Spain). Vol: 1 No: 1, Mei 2013. (online). Diakses pada tanggal 06 Desember 2016.http://pepsic.bvsalud.org/pdf/summa/v10n1/a06.pdf

Davis, S. F, Drinan. F. P dan Gallant. B. T. (2009). Cheating in School : What We Know and What We Can Do. Singapura: Wiley Blackwell.

Djamarah. (2011). Psikologi Belajar. Jakarta. Rineka Cipta.

Hasmayni, Babby. (2019). Prediction of Junior High School National Examination Score on the Leaming Achievement In High School Students In Medan. Proseding Seminar International. NICCT. Proceedings of the First Nommensen International Conference on Creativity \& Technology, NICCT. Jilid 1. hhtps://eudi.eu/proceedings/NICCT/2-19. EAI . hhtp://dx.doi.org/10.4108/eai.20-9-2019.2296598 
Hasmayni, B. (2020). The Difference of Academic Procrastination between Students Who Are Active and Not Active in Organizations Student Activity Units in the Faculty of Psychology University of Medan Area. Britain International of Linguistics, Arts and Education (BioLAE) Journal ISSN: 2685-4813(Online), 2685-4805(Print) Vol.2 (1): 411-421

H Simatupang, B Hasmayni. Perbedaan Minat Sekolah dan MotivasiBelajar Ditinjau dari Pola Asuh Orangtua. Jurnal Magister Psikologi UMA (Analitika). Vol: IV No: 1. Medan : Pasca Psikologi UMA

Hadjar Ibnu. (1996). Dasar-Dasar Metodologi Penelitian Kuantitatif Dalam Pendidikan. Jakarta: PT Raja Grafindo Persada.

Hamalik. (2001). Proses Belajar Mengajar. Bandung. Bumi Aksara.

Hartinah s. (2008). Perkembangan peserta didik. Jakarta: Aditama.

Hurlock, Elizabeth B. 1980. Psikologi Perkembangan Suatu Pendekatan Sepanjang rentang kehidupan.

Latipah, Eva. (2010). Strategi Self Regulated Learning dan Prestasi Belajar: Kajian Meta Analisis. Vol: 37 No. 1, Juni 2010. (online). Diakses pada tanggal 27 November 2016

https://www.google.co.id/url? sa=t\&rct=j\&q=\&esrc=s\&source=books\&cd=1\&cad=rja\&uact= 8\&ved=0ahUKEwiY2Jygr4jRAhWDs48KHUV9CmcQFggZMAA\&url=https\%3A\%2 F\%2Fjurnal.ugm.ac.id\%2Fjpsi\%2Farticle\%2Fdownload\%2F7696\%2F5962\&usg=AFQ jCNHZhbi0kRMzV9Ta3haTQTE0bZ8j9g\&sig2=SUc2CITtWWKBsVS8yeLIvQ\&bvm $=$ bv.142059868,d.c2I

Ormrod, Ellis. (2008). Psikologi Pendidikan Membantu Siswa Tumbuh dan Berkembang jilid 2. Jakarta: Erlangga.

Orosz G, Tóth-Király István, B"othe Beáta, Kusztor Anikó, Üllei Kovács Zsuzsanna and Miriam. (2016). Teacher Antusiasm: a potential cure of academic cheating. Vol: 6 No. 318, march 2015 (online). Diakses pada tanggal 06 Desember.

https://books.google.co.id/books?hl=id\&lr=\&id=L7DTCgAAQBAJ\&oi=fnd\&pg=PA42\&dq $=$ Teacher+Enthusiasm: $+a+$ potential+cure $+o f+$ academic + cheating \&ots $=z s 21 B y A T J d \& s$ ig=JiOXNsmWaDnkDwjOFuGg_kxKzWs\&redir_esc=y\#v=onepage \&q=Teacher\%20E nthusiasm\%3A\%20a\%20potential\%20cure\%20of\%20academic\%20cheating\&f=false

Purnamasari, Desi. (2013). Faktor-Faktor yang Mempengaruhi Kecurangan Akademik pada Mahasiswa Universitas Negeri Semarang. Vol: 2 No: 1, Oktober 2013. (online). Diakses pada tanggal $27 \quad$ November 2016.http://journal.unnes.ac.id/sju/index.php/epj/article/view/2581

Purwanto, N. (2007). Psikologi Pendidikan. Bandung. P.T. Remaja Rosdakarya

Purwanto. (2008). Metodologi Penelitin Kuantitatif Untuk Psikologi dan Pendidikan. Yogyakarta: Pustaka Belajar.

Santrock, W. (2004). Psikologi Pendidikan edisi kedua. Jakarta: Prenadamedia Group.

Santrock, J. W. (2007). Perkembangan Anak Edisi 11 jilid 2. Jakarta: Penerbit Erlangga.

Sari, Kartika. (2009). Perbedaan Interaksi Sosial Antara Siswa Yang MengikutiEkstrakurikuler Dengan Siswa Yang Tidak Mengikuti Ekstrakurikuler diSMPN 7 Medan. Universitas Medan Area. Skripsi tidak diterbitkan.

Sulaiman, et al. (2019). The Performance of Lecturer in the Development of Academic Culture in Ilmu Tarbiyah Al-Hilal College of Sigli. Budapest International Research and Critics Institute-Journal (BIRCI-Journal). P. 220-228

Suryabrata, Sumadi. (2005) Pengembangan Alat Ukur Psikologis, Yogyakarta,Penerbit Andi. Uno, M. B. (2005). Orientasi Baru Dalam Psikologi Pembelajaran. Jakarta. Bumi Aksara. 
Warsito, H. (2004). Hubungan Antara Self Efficacy Dengan Penyesuaian Akademik \& Perestasi Akademik. Jurnal Psikologi, vol. 14, No.2, Hal 92-109. Bandung : Fakultas Psikologi Universitas Padjajaran.

Whitley, E \& Speagel-keith. (2012). Academic Dishonesty An Educator's Guide. Lawrence Elbaum Associates New York. (online). Diakses pada tanggal 09 Desember 2016.

https://books.google.co.id/books?id=-

1B4AgAAQBAJ\&printsec $=$ frontcover \&dq=Academic + Dishonesty + An+Educator\%E2 $\% 80 \% 99 \mathrm{~s}+$ Guide $\& \mathrm{hl}=\mathrm{id} \& \mathrm{sa}=\mathrm{X} \& \mathrm{ved}=0 \mathrm{ahUKEwjL34XOsIjRAhXGKo8KHcAnASkQ}$ 6AEIGTAA\#v=onepage \&q=Academic\%20Dishonesty\%20An\%20Educator\%E2\%80\% 99s $\% 20$ Guide $\& \mathrm{f}=$ false

Wulandari Rien. (2014). Hubungan Self Efficacy Dengan Prestasi Akademik Pada Siswa Kelas XII SMA Negeri 16 Medan. Skripsi. Fakultas Psikologi Medan Area. (Tidak Diterbitkan). 